Palaeolithic Man at Gibraltar: New and Old Facts.

Author(s): L'Abbe H. Breuil

Source: The Journal of the Royal Anthropological Institute of Great Britain and Ireland, Vol. 52

(Jan. - Jun., 1922), pp. 46-54

Published by: Royal Anthropological Institute of Great Britain and Ireland

Stable URL: http://www.jstor.org/stable/2843770

Accessed: 09-04-2015 20:34 UTC

Your use of the JSTOR archive indicates your acceptance of the Terms \& Conditions of Use, available at http://www.jstor.org/page/info/about/policies/terms.jsp

JSTOR is a not-for-profit service that helps scholars, researchers, and students discover, use, and build upon a wide range of content in a trusted digital archive. We use information technology and tools to increase productivity and facilitate new forms of scholarship. For more information about JSTOR, please contact support @jstor.org. 


\section{PALAOLITHIC MAN AT GIBRALTAR: NEW AND OLD FACTS.}

\section{By L'Abbé H. Breuil, Litt.D. (Cambridge), Professor at the Institute of Human Palæontology, Paris. \\ I.-Discovery of a Mousterian Rock Shelter near Forbes Quarry.}

BeING in the war-service of the Naval Bureau and the French Embassy at Madrid, I was several times employed as diplomatic courier between Madrid and Gibraltar. It was during the short hours of one of these brief sojourns on the Rock, that, to employ my leisure time, I began to examine the foot of the slopes formed by the rocky rubbish of Forbes Quarry, to the north of the citadel.

I had already visited this place in 1914, with the regretted Colonel Willoughby Verner, and had assured myself that the old marine rock-shelter of Forbes Quarry was of no interest, and had never contained deposits other than marine gravels and a layer of stalagmite and clay, with the bones of very small mammals. Even the breccia of Forbes Quarry is no longer in situ, on account of a gigantic landslide ; the only traces are some scraps of wood, remains of sheds buried by the landslide. Between the quarry (Forbes Quarry) and the point where the road passes at the foot of the formidable vertical peak of Rock-Gun, which rises to the height of 413 metres, there is a deep cleft in the cliff, half filled up with a great mass of rubbish, on a very steep slope. This heap of rubbish is very old, and at the summit measures more than 100 metres in height; a number of shelters and numerous military trenches have been dug in it, which I visited in April, 1919, with Colonel Willoughby Verner, with the permission of the Governor of the fortress, but I noticed no remains of prehistoric age.

The slope of this cone of rubbish, instead of spreading in a normal way over the northern plain, on the contrary falls steeply, presenting inaccessible slopes, except towards the centre, where the erosion has cut out a breach, of which the ascent is very disagreeable and requires much precaution.

In all this mass, partly covered with a short grass towards the top, but of which the more or less agglomerate structure is visible in certain places near the foot, there are no remains of fossils to be seen except a great many terrestrial molluscs, principally Helix, which appear to be localised in the most recent layers; they belong to the period after the great landslides, when the slopes were formed, and when vegetation grew there.

To the east of these heaps of rubbish, and forming a counterpart to the quarry (Forbes Quarry), which encroaches on its western side, is another small. quarry; 
it is about 250 metres distant and behind some sheds, which are the only things between it and the road; it faces an old signal tower called the Devil Tower, and is at about 150 metres distance from it. The little quarry is almost deserted. It was there I wandered on the 28th April, 1917, in one of my moments of leisure. I noticed on the surface of the groove cut through the rubbish of fallen rock several little pieces of breecia containing fragments of bones; they were not in situ and must have rolled down from higher up the slope ; I climbed up the slope and soon found another handful of similar bones, and fragments of the teeth of deer and horse, evidently fossilized, and I reached thus a minute rock-shelter behind which they were numerous. At this moment a military policeman hailed me from the road, and forced me to interrupt my observations. After an examination of diplomatic passports, and having studied intently the handful of rubbish which I still clutched, he courteously requested me to keep to the road, and left me in peace.

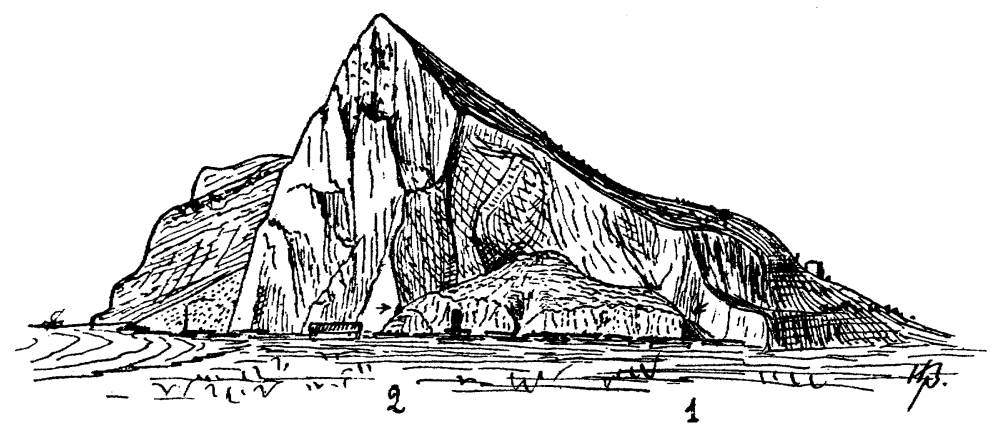

FIG. 1.-SKETCH OF THE NORTH FRONT OF THE ROCK OF GIBRALTAR, WITH THE “ BRECCIATED TALUS," BETWEEN FORBES' QUARRY (1) AND THE NEW MOUSTERIAN ROCK-SHELTER (2) OF DEVIL TOWER.

Thanks to the services of Colonel Willoughby Verner, I was able in April, 1919, to continue the examination of this place, the Governor very graciously conceding his permission, and it is of the results of this first short search that I wish to give an account. $^{1}$

The very shallow rock-shelter which attracts one's attention 15 metres above the quarry, is a fissure in the rock, the base widening into a little recess. Standing at the back of the rock shelter, and facing the Mediterranean, one notices that the left wall of the shelter (as one leaves it) is continued down to the foot of the hill by a rocky projection, which still remains; the right-hand limit of the deposit is, on the contrary, undetermined. The thickness of the rubbish in front of the rock-shelter is very great, at least ten metres deep, and I think that this rubbish masks a marine cave (similar to that of Grimaldi) of which only the top end in a cleft remained free

1 A short article on this subject appeared in the Gibraltar Chronicle and Official Gazette, of the issue of May 14th, 1919, under the signature of Colonel Willoughby Verner. 
of rubbish ; this must have fallen partly from the great peak which dominates the shelter, and be partly the ruins of the shelter itself, for one can see that the roof was originally much higher.

The top layers, visible in the rock-shelter near the entrance, have small sandy particles mixed with fragments of limestone, small bones, and minute débris of land and sea shells; the layers are horizontal and can be studied in section on the slope ; on several levels black deposits with fragments of charcoal are to be noted, testifying to human occupation. I had hardly time to examine them and cannot say their age. They form a little hanging terrace, affected by weathering, and certainly date from a time when the slope had not been eaten away at the base, but spread itself widely over the narrow plain, nearly reaching the edge of the sea. The sea level must have risen since those days, and come to bathe the base of the fallen scree, after the hanging horizontal layers of the rock-shelter were laid down. Anxious to know if the archæological and palæontological layers showed any considerable thickness, $I$ attacked the slope five or six metres lower down, cutting transversely to the axis of the rock-shelter. I found the soil consisted of fragments and blocks of rock mingled with calcareous earth, containing in certain places pebbles, sometimes scattered and sometimes conglomerate, in a form of "breccia." It is in this soil, resting on a rather sandier and red-coloured level, that the specimens were collected, principally in a dark layer, ill-defined, but which showed signs of human habitation.

Bones of Mammals. These bones are often whole and belong mostly to young animals, does, kids, young wild boar, and have been dragged there not by man, but by the panther, of which animal there are numerous remains. To the skill of human hunters must be attributed the rare fragments of giant ox and horse, and the bones (broken and burnt) of full-grown herbivores, and also of rabbits, which are common, as in all the Palæolithic layers of Andalusia. The lynx was also responsible for the increase in some of the layers of bones of rabbits and birds. Here is the list of mammals which M. Harlé has made out, verifying and confirming my previous study of them.

Ursus arctos. Some remains.

Felis pardus. Limb bones of adult panthers, rather small.

Felis pardina. Mandible and numerous bones belonging to at least two adult lynxes of small make.

Hyona striata (?). Coprolites, also fifth left metatarsal, which, though less massive, resembles those of the Hyona spelea, and can be compared to those of the Hycena striata.

Sus scrofa. A boar, at least one adult specimen and two young ones, of which one of the skulls is almost complete.

Cervus elaphus. Common deer of rather small build, at least two adult specimens, one young, and one very young (mandibles and hig bones not split by man). 
Capra ibex. Numerous remains of at least two adults and one young one.

Large ox. Adult and also very young specimens (few fragments), isolated teeth, astragalus, calcaneum.

Equus caballus. An upper molar, a fragment of a phalange.

Talpa sp. A small species, although adult, perhaps resembling more the Talpa coeca, a more southern type than the Talpa europea.

Lepus cuniculus. Rabbit, very abundant, some of the bones have been broken by man and burnt.

Arvicola sp. Small type ; mandible.

M. Harlé drew my attention to the fact that the bear, the panther, the lynx, the deer, the ibex, and the mole were all considerably smaller than the types found in the south of France.

Bones of Birds. There are a great many bones of birds, often of considerable size, in the tufa; their fragile consistency makes it difficult to extract them whole, except for the small kinds.

Mr. E. T. Newton kindly consented to identify these bones. (Extract of Mr. Newton's Report follows.)

"Fossil Avian Bones from a tufaceous deposit at Gibraltar, near Forbes Quarry, obtained by M. l'Abbé Breuil and Colonel Willoughby Verner and sent to E. T. Newton for identification on 3rd February, 1921.

“ A number of birds' bones obtained by M. l'Abbé Breuil and Colonel Willoughby Verner from a tufaceous deposit near to Forbes Quarry were sent to me for identification, and are of interest inasmuch as they add to our knowledge of the ancient fauna of this southern point of Spain. When these remains reached me they were in a fragmentary and fragile condition, and largely covered by tufaceous deposit. After cleaning and hardening, many of the pieces could be fitted together and portions of large bones partly restored. The most striking features of this series of fossil remains are a number of pieces belonging to Vultures, and more than a hundred small bones of the Alpine Swift. All the species identified are living forms.

"Vultur monachus, Linn. Several portions of large humeri, ulnæ, a metatarsal, and other parts of the skeleton agree with the corresponding parts of this species. These bones represent not fewer than three individuals. The distal ends of five ulnæ have each a deep pneumatic depression near its extremity, in which are the pneumatic foramina. Although present in each of these bones, this depression seems not to be a constant character of the species : for two skeletons in the Natural History Museum at South Kensington differ, one possessing similar depressions and the other not.

"Eagle (Halicetus sp.) To this genus is referred a portion of a sternum showing the two articulations for the coracoids overlapping in the mid-line. I have not found this condition in either Vultur or Aquila.-Eagle (?) A fragment of the distal

VOL. LII. 
end of metatarsal bone, much smaller than Vultur, is like that of Aquila and less like that of Halicetus.

"Brown Owl (Syrnium aluco, Linn.). The distal third of an ulna, which in size and form agrees with this bone in the Brown Owl, is referred to this species. It is unlike that of the Eared Owl or Barn Owl.

"Merlin (Falco cesalon, Tunstall). Half a tibia showing the peculiar arrangement of the tendon ridge, agrees precisely with that of the Merlin and not so well with that in the Kestrel. Also two humeri, one nearly perfect, are almost certainly of the same species.

"Kestrel (Falco tinnunculus, Linn.). A humerus wanting the head, and part of a metatarsal seem most near to the Kestrel.

"Swallow (Hirundo rustica, Linn.). A perfect humerus, undoubtedly represents the Swallow.

"Starling (Sturnus vulgaris, Linn.). A complete humerus more slender than that of the Thrush, agrees with that of the Starling.

"Common Chough? (Pyrrocorax alpinus (?)). Half an ulna smaller than that of the Common Chough is doubtfully regarded as the Alpine form.

"Alpine Swift (Cypselus melba, Linn.). The remains of a large Swift are very abundant in this series of fossil bones, there being about one hundred ulnæ and sixteen metacarpals. There is also a perfect metatarsal. The chief wing bones of the Swifts are so peculiar that there is little likelihood of their being mistaken for any other bird. The ulnæ are remarkably straight and robust, with peculiar articulations ; and such are these fossil ulnæ from Gibraltar, they have all the peculiarities presented by our Common Swift (Cypselus apus) but are longer and stouter, and indicate a much larger bird. Unfortunately no skeleton of the large Alpine Swift (C. melba) was available for comparison, but by the courtesy of the Natural History Museum at South Kensington I was allowed to uncover the arm bones of a skin of this species, and found they were identical in form with the fossil bones; the articulations, however, could not be clearly seen. But now I have been able to compare with a recent skeleton, most obligingly lent by the Abbé Breuil, and the identity of the recent and fossil bones is rendered doubly sure. The fossil ulnæ vary in size from $23.9 \mathrm{~mm}$. long by $2.8 \mathrm{~mm}$. wide to $27.3 \mathrm{~mm}$. long by $3.2 \mathrm{~mm}$. wide. The ulna of the recent skeleton is $25.4 \mathrm{~mm}$. long by $3.1 \mathrm{~mm}$. wide. Other species of Cypselus (C. maximus O. Grant, from Ruwenzori) have been described, but there is no reason to think that their bones would be materially larger than those of the Alpine form. The fossil metacarpals are imperfect, but they resemble the recent form, and I have no hesitation in including them in this species, and the metatarsal no doubt belongs to the same, its length is $14 \cdot 2 \mathrm{~mm}$. and the distal width $4 \cdot 0 \mathrm{~mm}$. The Alpine Swift was first described in 1741 from a Gibraltar specimen, where the species was said to occur in thousands. (See Garrod, British Birds, iv ed., Vol. II, p. 375.) 
"Barnacle Goose? (Bernicla leucopsis (?) Bechsh.). The distal half of an anserine metacarpal agrees in form with that of a White-fronted Goose, but is smaller and in this respect compares better with the Barnacle Goose.

" Rock Dove (Columba livia, Bonnat). Portions of seven humeri, one nearly perfect, together with ulnæ and coracoids, compare better with the bones of the Rock Dove than with other species of Columba.

"Red-legged Partridge (Caccabis rufa, Linn). This species is represented by portions of three femurs, an ulna, a scapula and a coracoid.

"Lapwing (Vanellus vulgaris, Bechsh.). The distal half of a humerus is the only bone referable to this species.

"All the species represented by these fossil bones are forms living at the present day at no great distance from the locality where the fossils were found, and consequently afford no clue as to the age of the deposit in which they occurred."

I notice amongst the specified birds numbers of ordinary rock-dwellers, as the Sea-eagle, Falcons, Eagles, Owls, Choughs, as well as Swifts, Swallows and Rock Doves. But the great black Vulture which is extremely rare to-day in Andalusia, ${ }^{1}$ and which nests in big trees and not in rocks, was then more common than it is to-day, and the presence of its bones would lead one to suppose that the Rock was then partially covered with forests. Since it does not nest in rocks it is more difficult to account for its presence here, but perrhaps it came to the corpses which the panther abandoned, and the panther may have killed the birds as an amusement. As for the Barnacle Goose, the Plover, and the Red-legged Partridge, it was probably the lynx which devoured them.

Reptiles and Batrachians. Some remains of tortoises and big toads.

Shells. These have been classed by M. Paul Fischer, who published the result in the Journal de Conchyliologie, 1920, p. 389. The sea shells have been brought by man and have served for his food.

Mytilus gallo provincialis, Lam. The thick and brilliant nacre of the Gibraltar specimens resembles an exclusively Atlantic species Mytilus afer of western Morocco, which does not exist at Gibraltar. The mussels were of great size and fairly plentiful in the tufa, but were as a rule difficult to excavate on account of their fragility.

Patella vulgata, L. Show the shape and markings generally to be found in the Atlantic type or in those found in Britain. There are numerous specimens.

(?) Meretrix chione, L. Fragments.

The terrestrial shells are there in their natural state; they are most frequent in the surface layers of the scree and in the tufa, but from the latter they are difficult to extract.

Helix (Otola) marmorata, Fer. and Helix balearica, Zieg., with intermediary forms showing once more that instead of considering these as two species they can be treated under one heading.

1 My Life among the Wild Birds of Spain, Chapter V, Willoughby Verner. 
Rumina decollata, L. A variety.-These species are still in existence in the district.

Industries and other human remains. The presence of man is first shown by the traces of hearths, burnt bones, and calcined stones scattered in the layers, but up till now stone implements are scarce. Except for ten shapeless flakes of flint, quartzite or hard limestone, we can only base our morphological theories on four objects: (1) a superb flint side scraper with a marked white patina (Fig. 2, 1), the flake surface very curved and perfectly retouched. It is exactly like the side scrapers of La Quina and Le Moustier ; (2) A quartzite disc, greyish-brown in colour (Fig. 2, 2) and a blade of the same material (Fig. 2, 3), thick and with a broken end and some notches made by use on the right edge ; (3) another blade of flint, thinner, of the same material, but as irregular as the preceding one; the two outside edges are

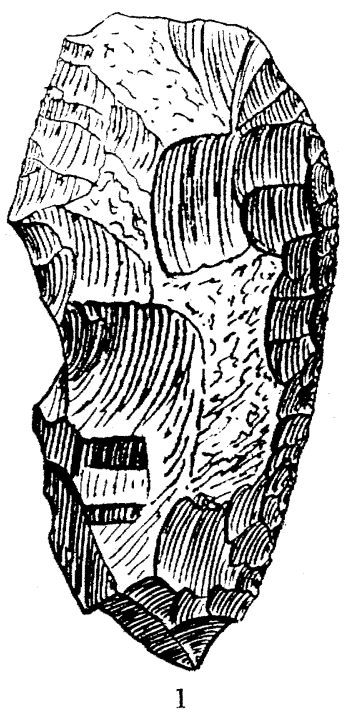

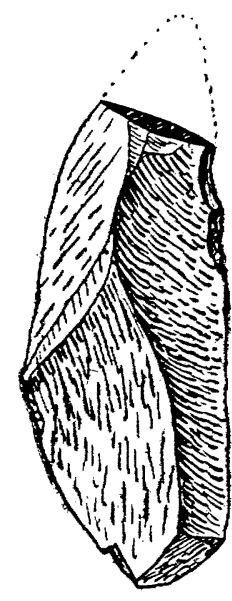

3

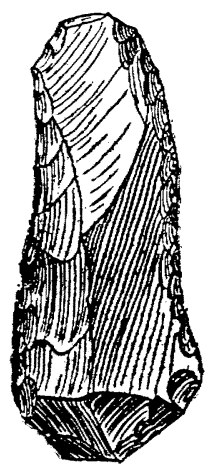

4

FIG. 2.-MOUSTERIAN IMPLEMENTS OF THE NEW ROCK-SHELTER : 1 AND 4 ARE OF FLINT, 2 AND 3 OF QUARTZITE. $\frac{3}{4}$.

carefully notched (Fig. 2, 4). The make of these two blades show them to be purely Mousterian. The character of these four specimens shows them to be of Upper Mousterian age. I found no trace of worked or utilized bone. ${ }^{1}$

To all appearance the continuation of the excavations on this level, as they approached the floor of the rock-shelter, will expose the centre of the "hearths," of which only the outside edge is projected.

A thorough search would involve much excavation, starting with the upper layers which I left undisturbed, and it might be that in the mass of debris, 10 metres thick, older layers than those which I broke into may be discovered.

1 I examined, at Cambridge, thanks to the kindness of Professor Duckworth, the flints of which he speaks on p. 561 of his article, "Cave Exploration at Cibraltar in September, 1910." (Journal of Royal Anthropological Institute, 1911), and, contrary to the opinion of Dr. Sturge, I think none are of earlier than neolithic date. 
The Quaternary age of those I examined is undeniable, as also that of the contained industries of Mousterian date. ${ }^{1}$

It is needless to insist further on the importance of these affirmations when one remembers the additional evidence given by the discovery, in 1848, by Lieut. Flint, of a Neandertaloid skull in Forbes Quarry. The great number of bones of panther, lynx, and vulture, the immaturity of many of the collected skeletons, and the fact that in their original state the bones were so little fractured, seems to show that man played but a small part in their accumulation, and that one is dealing with a lair of carnivorous beasts, though man also frequented the neighbourhood.

\section{II.-Documents Dealing with the Old Excavations at Gibraltar.}

I think it is interesting to note that the Abbé Gaudefroy, Professor of Mineralogy at the Catholic Institute, gave me last year two documents (old manuscripts) dealing with the excavation of the Gibraltar Rock shelters by Captain Brome, ${ }^{2}$ one written in Spanish and the other in English. The latter is an account of diggings made by the Captain between 1864-68, earlier than those the account of which is published by Busk ; he tells of the results of excavations in a cleft to the east of Genista Cave, containing the bones of rhinoceros, of a very large deer, etc. This fissure was connected with Genista Cave, and according to him may have been the way the bones were brought in. I will return to this subject later. He then recounts the more recent discoveries made in other rock shelters on the Rock, either in the neighbourhood of Genista Cave, Martin's Cave (neolithic and mediæval), Fig-tree Cave (same), St. Michael's Cave (same). Then he told of the discovery of subterranean galleries leading from the preceding cave, which he called "Leonora's Cave," in which he only makes mention of the beautiful stalactites. I visited these galleries in 1914 without finding anything of interest, except a few rubbed-out remains of yellow paintings, absolutely indecipherable.

1 The Mousterian civilization had reached the same stage as in the neighbouring Andalusian region. The nearest stations are those of Pasada of Gibraltar, near Casas Viejas (Cadiz), Cerrito de la Campanilla near Acizcar at Facinas (Cadiz), different isolated finds of Facinas itself. and Taivilla and Bolonia (Cadiz). At a little distance we can mention the great open-air workshop at Bobadilla (Malaga), and much farther away, the rock shelter excavated by L. Siret, in the province of Almeria (the caves of Zajara and las Perneras), and in the province of Murcia Palomarico at Mazarron, and la Vermeja at Carthagena. I myself found a big Mousterian workshop at Minateda (Albacete). Only the stations discovered by L. Siret can boast a beautiful industry comparable to that of Dordogne and Charente.

2 These accounts confirm, on various points, the far more detailed report of G. Busk (on the cave of Gibraltar, in which human remains and works of art have been found) read at an International Congress of Prehistoric Archæology at Norwich in 1868, p. 106-166; an account of the Judge's cave (p. 144-9), actually on the property of Mr. James L. Imossi, which I visited with Colonel W. Verner in 1919, and of which the original entrance is blocked with earth and rubbish, and which should have an exit in the neighbouring ravine of Buena Vista. I noticed some fragments of rough pottery and some animals' bones of probable neolithic age. 
The second document, in Spanish, is not signed; it is entitled "Copy of some observations on the collection of fossils in the caves Genista, Martin, etc., at Gibraltar, in the possession of the Bishop of Antinoe." This report says that Captain Brome gave to this prelate an important collection coming from the Genista Cave, annotated in his handwriting, and there is also mention made of a note by the same author, attached by the excavator to the fossils preserved in the college of San Bernardo at Gibraltar. ${ }^{1}$

The stratigraphy of the rock shelter is thus described.

1. The first bones were discovered at a depth of 23 feet; from 23 to 30 feet various fossils were found, with bivalve marine shells (armejas) of various kinds.

2. From 30 to 38 feet, limestone, quartz pebbles (guijarros) and earth. From 38 to 50 feet red breccia, the teeth of rhinoceros, bones of ruminants, birds, rolled quartz pebbles, flints.

3. From 53 to 59 feet, the bone-strewn breccia continues ; a human milk tooth, some flint implements, of which one is a knife.

4. From 69 to 100 feet the bony breccia continues with scattered bones, teeth, and quartz pebbles.

The unknown author of this article discussed afterwards some of the discovered facts. He did not admit that man existed at the time of the formation of the breccia in Genista Cave; questioned the human working of the shaped flints, and thought the character of the Forbes Quarry skull purely accidental. In all these points he seems badly inspired. He probably was so, even as regards the criticism of the explanation given by Busk and Falconer of the accidental introduction of such a mass of bones into the cave, but he himself expresses no opinion.

$\mathrm{He}$ is quite right in thinking that it is not the force of gravity which mixed in the breccia so many bones of animals, creatures which naturally died outside the cave, remains which include fish, sea shells, and the bones of birds. The most probable conclusion is that the greater part of these bones was brought there by carnivorous beasts, by man, and as regards the smallest, by great birds of prey.

Genista Cave, with flints, travelled pebbles, bony breccia, is therefore a deposit representing a haunt of beasts of prey, and a human palæolithic station, the existence of which was unknown at the date of the excavations. It would be interesting if we could find again the flints mentioned in the catalogue, and the human milk tooth from the red breccia. ${ }^{2}$

1 In the work of Busk (Norwich) the statigraphy is less clearly set forth; but in the 53-foot deep layer mention is made of the discovery in the red breccia of two rhinoceros molars, of a flint knife, and of numerous flakes of very large size. There was also a human milk tooth, not worn. In the top layers, which have a thickness of 20 feet, formed also of red breccia, they were beginning to discover flints, rolled pebbles, and bones. These two documents (Busk and that written in Spanish) agree so closely that they are evidently based on the work of Captain Brome.

${ }^{2}$ I desire to give hearty thanks to my friend Miles Burkitt for translating my French manuscript into English.-H. B. 